\title{
The Narrative Experiences of Undergraduate African American Male Students, 24 Years and Younger, who Successfully Transitioned to and Persisted in College
}

\section{Darrick Tovar-Murray}

This study investigated the narrative experiences of undergraduate African American male students, 24 years and younger, who successfully transitioned to and persisted in college. In particular, this study explored the non-cognitive and environmental factors that influence persistence. Employing a qualitative research design, the author conducted focus group interviews with academically successful undergraduate African American male students $(n=13)$. Three main themes emerged from the data: (1) confronting non-cognitive and environmental challenges to persistence, (2) colleges and universities playing a major role in persistence rates, and (3) same-race peer groups enhancing academic potential. Implications and recommendations for institutions of higher education are discussed.

The postsecondary educational experiences of African Americans are well documented in the higher education literature. Current national educational trends reported by the American Council on Education (2008) and Council of Graduate School (2008) indicated that African Americans have made solid gains in postsecondary participation, retention, and persistence rates. Each year the number of African Americans enrolled in undergraduate and graduate programs reaches a new high as the number of college degrees awarded continues to increase. For instance, in 2007, a total of 146,653 bachelor's degrees were awarded to African Americans, representing a 3\% increase from the previous year (Anonymous, 2009). Although there are reasons to be optimistic about these current educational trends, another look at the statistics indicates that for undergraduate African American males between the ages of 18-24, college completion rates continue to recede far behind those of all other gender and racial groups (Anonymous, 2009).

Still other higher educational trends have found that, when compared to White male students within the same age range of 18-24, African American male students' college participation rates were much lower (46\% to 40\%, respectively) (KewalRamani, Gilbertson, Fox, \& Provasnik, 2007). Also, the American Council on Education $(2005,2008)$ consistently reports that the college graduation rates 
of African American male students tend to lag significantly behind those of their White male student counterparts. That is, undergraduate African American male students' college completion rate is approximately $20 \%$ less than their White male counterparts ( $31 \%$ to $49 \%$, respectively). For every two White male students who depart from college, three African American male students drop out (Cabrera, Nora, Terenzini, Pascarella, \& Hagedorn, 1999). Even more striking than this racial gap is the within-group disparity-the number of African American male students who enter college is much greater than the number of those who actually complete college (KewalRamani et al., 2007).

Further examination of a broad range of postsecondary education data clarifies that undergraduate African American male students' underachievement is a function of non-cognitive and environmental variables such as microaggressions. Microaggressions are often subtle and automatic exchanges of racial indignities (e.g., "I do not think that you are Black") and can take on many forms, verbal and/or nonverbal (Franklin \& Boyd-Franklin, 2000). Using a critical race theory framework, Solorzano, Ceja, and Yosso (2000) found that microaggressions are a unique source of stress for African American male students that exists in both academic and social spaces on college and university campuses. In addition, microaggressions tend to be associated with negative collegiate racial climate and high college drop-out rates among undergraduate African American male students (Smedley, Myers, \& Harrell, 1993; Solorzano et al., 2000).

Two models, Student-Institutional Fit and Transactional, have been used to examine the influence of microaggressions on undergraduate African American male students' low persistence rates. First, the Student-Institutional Fit Model holds that students enter an academic system that is characterized by academic integrations (grade performance and intellectual development) and social integrations (peer group interactions and faculty interactions) that work together to influence students' goal commitments and institutional commitments (Tinto, 1975). Proponents of the Student-Institutional Fit Model argue that microaggressions tend to negatively interfere with undergraduate African American male students' academic integrations and social integrations and play a key role in their decision to leave college. Therefore, drop-out rates are influenced by how well undergraduate African American male students adjust to the cultural structure and academic life of college (Pantages \& Creedon, 1978; Pascarella, 1982; Tinto, $1975,1987)$. That is, what goes on within an institution, such as racism and low tolerance, following enrollment (Bridglall \& Gordon, 2004) is related to persistence rates (Tinto, 1975), and the greater congruence between a student and the institution, the more likely that he or she will become integrated into the college life and persist.

The second model is the Transactional Model. This model holds that stressors can upset a person's balance and negatively impact an individual's academic achievement, leading to low persistence rates (Cabrera et al., 1999). The Transactional Model regards microaggressions as psychological and sociocultural stressors that, over time, can lead to maladjustment behaviors and low academic resilience (Smedley, Myers, \& Harrell, 1993). In other words, microaggressions tend 
to negatively impact collegiate racial relationships, which can lead to undergraduate African American male students developing maladjusted behaviors at their respective institutions to cope with the stress associated with racism. Unlike other stressors, however, microaggressions are considered unique in that they are exclusively related to minorities. These subtle forms of racism can lead to a primary effect of feeling unwelcomed, causing undergraduate African American male students to drop out of college before completing their degrees (Cabrera et al., 1999; Smedley et al., 1993).

Despite the overall educational trends and conceptual advancements made in understanding undergraduate African American male students' persistent rates, inferences regarding the effects of non-cognitive and environmental factors are inconclusive. What is even more striking is that some African American males between the ages of 18 and 24 are able to avoid the hardships that beset other students on predominantly White college and university campuses. Relatively few studies (Harper, 2006; McClure, 2006) have focused on how some African American male students have been able to overcome the non-cognitive and environmental barriers that tend to spill over into their academic life. Therefore, the aim of this study was to give voice to these experiences. This study was guided by the following questions:

1. How are selected undergraduate African American male students able to be persistent at predominant White colleges and universities?

2. How do same-race peer relationships give voice to those experiences?

\section{Method}

\section{Participants}

Demographic Information. A total of 13 undergraduate African American male students attending a large, Midwestern university were invited to participate in this study (see Table 1). The ages of the participants ranged from 18 to 24 years old, with an average age of 21 . The researcher purposefully chose undergraduate African American male students between the ages of 18 and 24 because of high incarceration and college drop-out rates. In this study, the students participated in a focus group and were selected based on same-race peer group affiliation (i.e., student organizations). All participants reported having at least a 3.0 grade point average (GPA) and were juniors or seniors at the time of the study.

Participant Recruitment. A snowball sampling procedure was used to identify participants. This procedure is one in which subjects aid in the recruitment of additional potential participants with which they are acquainted (Patton, 2002). In addition, participants were contacted by the primary researcher and invited to participate in a focus group, by word-of-mouth, and through the posting of flyers. The criteria for being selected to be a part of this study included academically successful undergraduate African American male students, 24 years and younger, who reported same-peer group affiliation. The resulting sample was made up of individuals who arrived at the focus group at the designated time and place and 
consented to participate. Analyses are based on summaries of the focus group that consisted of 13 African American males.

Data Collection. A 2-hour focus group was the primary data collection used for this study. Participants responded to a series of open-ended questions, such as: "Would you generally speak about your experience at the university?" Prior to taking part in the focus group, all of the participants signed a consent form and completed a demographic form asking their grade level and grade point average. During the focus group, the participants engaged in a dialogue about their academic and social experiences on campus. The focus group interview was audio-taped; observations regarding how the participants responded to questions and their willingness to engage in the focus group were recorded. In order to maintain confidentiality of the participants, the primary researcher removed all identifying information (e.g., names) and gave the participants pseudonyms.

Following the completion of the focus group, the audiotapes were transcribed verbatim by the primary researcher. A contact summary sheet was developed that covered the following areas: (a) themes and issues occurring during the focus group interview, (b) a summary of the focus group interview, and (c) discussion of items that were of interest during the focus group interview. After the data were collected and transcribed, the primary researcher coded the data into units of themes to look for expressions of ideas.

\section{Qualitative Data Analysis}

Data analysis employed a grounded theory approach. Grounded theory is a systematic qualitative methodology that involves induction, deduction, and verification of data (Glaser \& Strauss, 1967). Strauss and Corbin's (1990) coding procedures for grounded theory were used for this study. First, the process began with open coding whereby the transcript text was broken down into distinct parts, and concepts that arose from data were identified. Next, the data were analyzed using a selective coding method, and core categories were woven together to create themes. Finally, axial coding was used to put the data back together. The process continued until the data reached a point of saturation.

To ensure authenticity of the findings, the researcher used a variety of qualitative techniques. First, thick description and detailed account of participants' narratives were employed to capture the phenomenon that was being studied. Next, to ensure the data's trustworthiness, a detailed summary of the findings was sent to all participants for review and to ensure their concordance. Finally, to increase credibility, multiple sources were used to triangulate the data. As a result, literature reviews, focus group data, and field notes were used as a means of establishing credibility (Denzin \& Lincoln, 2003).

\section{Results}

A general summary of the findings derived from the data were organized in the 
following three themes or sections: (1) confronting non-cognitive and environmental challenges to persistence, (2) colleges and universities playing a major role in persistent rates, and (3) same-race peer groups enhancing academic potential. These themes were developed from the results of the analysis of the focus group transcripts. Each of these themes will be discussed, with quotations taken from the focus group participants to illustrate main themes or patterns.

\section{Theme One: Confronting Non-Cognitive and Environmental Challenges to Persistence}

Many participants recounted stories in which they had to confront noncognitive and environmental challenges on campus in order to persist academically. In general, microaggressions, which referred to confronting daily and often subtle forms of racial indignities, were often indicated by the participants as the greatest challenge. These racial indignities tended to be expressed in the form of laudatory comments such as, "You're a credit to your race" or such questions as, "Do you play basketball?" As a result of these comments or questions many participants reported feeling "isolated and marginalized," with negative spill-over into their academic performance.

"Whether in the classroom or outside of the classroom," said Participant D, "a lot of times I had to deal with people's stereotypes. Being the only Black male in my classes, people sometimes thought that I was on an athletic scholarship or an exceptional person for being in the engineer[ing] program. At first, these types of things bothered me, as I was not prepared to deal with people questioning me." Participant D also described how these racial indignities negatively spilled over into his college experience and how his academics suffered due to not being able to cope with the cumulative effect of "hearing insulting and dehumanizing" comments.

Participant G said, "Dealing with negative stereotypes can hinder your individual performance" as he reported spending his first two years in college "trying to dispel myths about being Black." He also said that having to constantly fight negative stereotypes almost made him drop out of school: "I spent a lot my time trying to act, speak, and think how others behaved, spoke, and thought. And my first two years were very difficult for me. My grades suffered and I contemplated whether I belonged here or not."

Participant A reported, "The bottom line is that you can't let others deter you from reaching your goals. You kind of got to not let yourself become preoccupied with negative stereotypes and keep your eyes on graduating." Despite the negative spill-over effect, all participants found ways of coping with microaggressions through positive extracurricular activities on campus and strong mentoring relationships with other African Americans to enhance their selfdevelopment and identity.

While many of the participants wanted to believe that American colleges and universities were post-racial, being Black on campus posed a paradox-another 
challenge identified by the participants. Based on several conversations with participants, this paradox was identified as constantly being mindful of how one's skin color is profoundly visible to others; at the same time, their Blackness provided them with a platform from which to discuss with others "the plight of the Black man." Participant K said, "My skin is forever present in the eyes of others, so I use this to my advantage and educate those who are curious about me." Participant J also saw this paradox "as an opportunity to educate others about the struggles of Black men."

Unfortunately, many participants felt overwhelmed trying to make this "peaceful journey," and Participant L equated the primary feeling associated with this paradox to "losing your soul" as he felt that he was "always under a microscope." Here, "losing your soul," as explained by Participant I, referred to making every attempt to "hold on to your Blackness and integrity while openly confronting stereotypes." By maintaining integrity during times that challenged other Blacks, students carried with them "this drive to be successful and to prove to others that they were wrong," said Participant B.

Many participants felt that they were "doubly disadvantaged" as being both Black and poor. This challenge exemplifies what some have called "the double-whammy effect" as many participants were doubly disadvantaged by "being Black and coming from economically poor communities." An example of this is found in a statement made by Participant C, who said, "Being Black is hard, but being a poor college student is even harder. As a poor Black college student I have to not only prove to Whites that I belong here, but I have to prove to my own community that I am still Black enough." In this example, being "Black enough" was consistent with Fordham and Ogbu (1986), Lundy (2003), and Noguera's (2003) notions that environmental forces can shape school performance. Furthermore, due to historical oppression, young African American males have formed an oppositional culture that sometimes persuades same-race peers to devalue academics or to avoid "acting White."

In other words, as described by most participants, being an African American male from a disadvantaged community often meant that you were exposed todirectly or indirectly-harsh treatment by authority figures. This, in turn, created the sentiment among young and economically disadvantaged Black males that "going to school was seen as acting White and not keeping it real," said Participant A. In addition, Participant H, who struggled during his first year, said, "Many of us want to be successful, but it is hard to concentrate on academics when you have to find ways to pay for your tuition. We need scholarships for us to make it here." The notion of not having enough resources to fund education presented a major challenge for all of the African American males in this study.

\section{Theme Two: Colleges and Universities Playing a Major Role in Persistence Rates}

After discussing key challenges in their college experiences, the participants 
turned much of the conversation towards how the university could focus its efforts on providing young, Black male students with adequate resources to persist. At first, a belief was expressed that "as a Black male you are on your own," as articulated by Participant F. However, when asked about educational and social resources, many participants replied that the university does provide the means to be successful. For example, the minority-focused programs were cited by the participants as being most helpful, but "there are not enough social events for us" said Participant G. He also said, "We spend our time here going to clubs and drinking which takes away from our grades. We should be going to some of the university programs instead of hanging out at clubs." Participant J said, "The university does a good deal with diversity programs, and many of these programs are geared towards the Black life experience." Participant B agreed with Participant $J$ and stated that the university provides them with programs that focus on their lived experiences and "what we need to do to be successful."

An excerpt from Participant I's narrative echoed this notion as he said, "I enjoyed going to programs and talking about diversity. After leaving those programs, I feel empowered and part of a community." In the same vein, three other participants said that the minority-focused programs on campus stress the importance of academic success, promote cultural awareness, provide opportunities to learn about others, and create an environment of freely exchanged dialogue. In addition, participants also frequently cited the university's ongoing mentoring program as a critical resource.

\section{Theme Three: Same-Race Peer Groups Enhancing Academic Potential}

The final theme that emerged from the data related to how same-race peer group support cultivates students' academic persistence. Most importantly, same-race peer groups provided the African American male students with a positive peer culture that buffered perceived racial differences as well as offered an avenue in which "to give back to the community," said Participant E. This point was further illustrated by Participant L, who said, "Being a member of a Black fraternity gives me the tools to be a leader and the skills to be a positive role model for others." Participant F saw same-race peer groups as providing him "... a strong sense of brotherhood and accountability." He also said that "being part of the Black student organization made me realize that I am my brother's keeper and that I need to be a responsible member of society." Participant M, who was part of the Black Greek system, perceived his organization as helping him negotiate his way through college. He said, "Coming from a broken family is difficult, and my brothers are positive examples for me to follow. These brothers are here to support me and show me what it is like to be a strong Black man." Additionally, same-race peer groups provided African American male students with opportunities to connect with other ethnic minority staff members who served as advisors to organizations. 


\section{Limitations}

This qualitative study investigated the narrative experiences of success of undergraduate African American male students at one large, Midwestern campus. As with all studies, there are some limitations with respect to generalization, population, and setting. First, given that the research design used for this study was qualitative, current findings do not establish any causal relationships among the variables of interests, and the results cannot be generalized to the entire population of undergraduate African American male students. Second, since the population used for this study consisted of successful undergraduate African American male students who belonged to same-peer groups, the voices of students who are not part of Black student organizations on this campus were not heard. Finally, the majority of the sample studied was taken from a heterogeneous undergraduate African American community, and this setting could have impacted the results. Therefore, the author recommends that future research include undergraduate African American male students from multiple locations, expanded age groups, and divergent social classes.

\section{Discussion}

The results of this study have given voice to a topic that tends to be ignored in the higher education literature. First and foremost, the findings of this study supported the existing knowledge base (Franklin \& Boyd-Franklin, 2000; Smedley et al., 1993; Solorzano et al., 2000; Tinto, 1975, 1987) and found that noncognitive and environmental stressors on campus such as microaggressions play a key role in undergraduate African American male students' persistence to graduation. In this study, many of the participants viewed prejudicial attitudes and behaviors as factors interfering with their individual educational goals and institutional commitments, therefore limiting their ability to meet the academic demands of college (Tinto, 1975, 1987). Thus, many of the participants also reported that microaggressions tend to be associated with a less than amicable collegiate racial relationship, thereby resulting in a lack of social integration on campus.

The current results support prior research (Anderson, 2006; Cuyjet, 2006) which found that access to resources and mentorship is related to undergraduate Africans American male students' persistence to graduation. For example, many of the participants, especially those who were from economically disadvantaged backgrounds, reported that they were unable to bear the full cost of going to college and that having to worry about finances detracted from their academics. Not only did finances negatively impact their academics, but the lack of African American male mentors to help them successfully navigate the educational system influenced their academic and social integrations on campus. These findings tend to suggest that for some undergraduate Africans American male students continued persistence may be more related to finance and available resources than the 
"burden of acting White" (Fordham \& Ogbu, 1986) and/or some type of antagonism to education.

As they pertain to the role that colleges and universities can play in undergraduate African American male students' persistence to graduation, the results of this study indicate that ongoing academic and social support may decrease drop-out rates. Such support can come in the form of financial aid, mentoring relationships, and educational programs that actively address academic and social integration issues on campus. Some key features of these programs that were identified by the participants included decreasing the financial cost of education, improving mentor relationships, and increasing cultural awareness.

This study is consistent with past research (Harper, 2006) which found that one ultimate resolution towards academic success for undergraduate African American male students comes in the form of a same-race peer group. Same-race peer group refers to a "collective identity based on one's perception that one shares a common racial heritage with a particular racial group" (Helms, 1990, p. 3). In this study many of the participants considered same-race peer group to be an important source of "social capital" (Coleman, 1988) that provides them with assistance through structural (e.g., network size) and functional (e.g., emotional support) relationships. In other words, same-race peer group provides undergraduate African American male students with a mechanism to disrupt the influence of negative non-cognitive and environmental factors on college campuses as well as a voice for them to express their individual educational and cultural goals.

\section{Implications for Colleges and Universities}

In addition to the aforementioned findings, several practical implications for colleges and universities emerged from the results of this study. First, given that microaggressions are stressors that exist on campus, colleges and universities must develop cultural awareness programs. These programs must explore inter-group and intra-group stereotypes as well as promote a safe and healthy racial campus climate. In addition, colleges and universities can develop initiative programs such as the ones at DePaul University (e.g., Male Initiative Project) and Northern Illinois University (e.g., Black Male Initiative). These initiatives, to some degree, tend to focus on new student transition to college life, academic enrichment and career development, social integration and leadership development, and mentorship and community engagement. The overarching goal of these programs is to academically and socially integrate undergraduate African American male students on campus so that they can successfully transition to and persist in college.

Next, colleges and universities must recognize that the road to academic success for undergraduate African American male students is often a circuitous process-one in which college tuition and other financial resources directly impact persistence rates. In this study, many of the participants came from 
low- and moderate-income households that lacked economic resources to support their educational endeavors. Given their socioeconomic status, colleges and universities need to develop tuition assistance programs that can provide undergraduate African American male students with scholarships, financial aid, and tuition reimbursement to offset the high cost of college and other living expenses. Most importantly, African American male students also need other educational and mentoring opportunities to make positive connections with faculty and staff which can only enhance their academic performance and social integration.

Finally, institutions of higher education, through their student affairs divisions, should ensure that all undergraduate African American male students have opportunities to engage with formalized same-race peer groups. These groups may provide them with information and mentorship that is apparently necessary for academic success. Also, same-race peer groups help to provide undergraduate African American male students with a social space for racial solidarity, thereby integrating them in the academic and social spheres of college life. 
TABLE 1

\section{Description of Sample}

Participants Age GPA Classification Major

\begin{tabular}{|c|c|c|c|c|c|}
\hline Participant A & 21 & 3.0 & Senior (4 year) & Education & Student Organization \\
\hline Participant B & 20 & 3.2 & Junior (3 year) & Business & Student Organization \\
\hline Participant C & 21 & 3.1 & Senior (4 year) & Graphic D. & Student Organization \\
\hline Participant D & 22 & 3.0 & Junior (3 year) & Engineer & Black Fraternity \\
\hline Participant E & 21 & 3.4 & Junior (3 year) & Social Work & Student Organization \\
\hline Participant F & 22 & 3.3 & Senior (4 year) & Political Sci. & Student Organization \\
\hline Participant G & 23 & 3.0 & Junior (3 year) & Education & Black Fraternity \\
\hline Participant $\mathrm{H}$ & 22 & 3.0 & Junior (3 year) & Biology & Black Fraternity \\
\hline Participant I & 20 & 3.2 & Senior (4 year) & Education & Student Organization \\
\hline Participant J & 22 & 3.0 & Junior (3 year) & History & Student Organization \\
\hline Participant K & 21 & 3.2 & Junior (3 year) & Psychology & Student Organization \\
\hline Participant L & 23 & 3.1 & Senior (4 year) & Art & Black Fraternity \\
\hline Participant M & 21 & 3.4 & Senior (4 year) & Journalism & Black Fraternity \\
\hline $\mathrm{N}$ & 13 & & 13 & & \\
\hline Mean & 21.46 & & 3.14 & & \\
\hline SD & 1 & & 0.14 & & \\
\hline
\end{tabular}

Same-Race Group Affiliations 
American Council on Education. (2005, November). College students today: A national portrait. Retrieved November 8, 2009, from http:www.acenet.edu

American Council on Education (2008, October). Generational gains in postsecondary education appear to have stalled, new ACE report finds. Retrieved November 8, 2009, from http://www.acenet.edu/AM/Template.cfrm?Section=Press

Anderson, Z. (2006). Literature review: Why are there fewer undergraduate African American men in college than undergraduate African American women? The University of Michigan Research Forum, 1(3), 34-37.

Anonymous. (2009, July). A harvest of good news on African Americans in higher education. The Journal of Blacks in Higher Education. Retrieved November 8, 2009, from http://www.jbhe.com/news_views/64_goodnews.html

Bridglall, B. L., \& Gordon, E. W. (2004). Nurturing talent in underrepresented students. Pedagogical Inquiry and Praxis, 6, 1-6.

Cabrera, A. F., Nora, A., Terenzini, P. T., Pascarella, E., \& Hagedorn, L. S. (1999). Campus racial climate and the adjustment of students to college: A comparison between White students and African-American students. The Journal of Higher Education, Columbus, 70(2), 134-160.

Coleman, J. S. (1988). Social capital in the creation of human capital. The American Journal of Sociology, 94, 95-120.

Council of Graduate Schools. (2008). Graduate enrollment and degrees report. Retrieved November 8, 2009, from http://www.cgsnet.org/Default. aspx? tabid $=168$

Cuyjet, M. J. (2006). African American men in college. San Francisco: Jossey-Bass.

Denzin, N. K., \& Lincoln, Y. S. (Eds.) (2003). Collecting and interpreting qualitative materials (2nd ed.). Thousand Oaks, CA: Sage.

Fordham, S., \& Ogbu, J. (1986). Black students' school success: Coping with the "burden of acting White." The Urban Review, 18(3), 176-206.

Franklin, A. J., \& Boyd-Franklin, N. (2000). Invisibility syndrome: A clinical model of the effects of racism on African-American males. American Journal of Orthopsychiatry, 70(1), p. 33-41.

Glaser, B. G., \& Strauss, A. L. (1967). The discovery of grounded theory: Strategies for qualitative research. New York: Aldine Publishing Company.

Harper, S. R. (2006). Peer support for undergraduate African American male college achievement: Beyond internalized racism and the burden of "acting white." The Journal of Men's Studies, 14(3), 337-358.

Helms, J. E. (Ed.). (1990). Black and White racial identity: Theory, research, and practice. Westport, CT: Praeger Press.

Jackson, J. F. L., \& Moore, J. L., III. (2008). Introduction: The African American male crisis in education: A popular media infatuation or needed public policy response. American Behavioral Science, 51(7), 847-853. 
KewalRamani, A., Gilbertson, L., Fox, M., \& Provasnik, S. (2007). Status and Trends in the Education of Racial and Ethnic Minorities (NCES 2007-039). National Center for Education Statistics, Institute of Education Sciences, U.S. Department of Education. Washington, DC.

Lundy, G. F. (2003). School resistance in American high schools: The role of race and gender in oppositional culture theory. Evaluation and Research in Education, $17(1), 6-27$.

McClure, S. M. (2006). Voluntary association membership: Black Greek men on a predominately White campus. The Journal of Higher Education, 77(6), 1036-1057.

Noel, L. (1976). College student retention-a campus-wide responsibility. Journal of National Association of College Admissions Counselors, 21(1), 33-36.

Noguera, P. A. (2003). The trouble with Black boys: The role and influence of environmental and cultural factors on the academic performance of African American males. Urban Education, 38(4), 431-459.

Pantages, T. J., \& Creedon, C. F. (1978). Studies of college attrition: 1950-1975. Review of Educational Research, 48(1), 49-101.

Pascarella, E. T. (Ed.) (1982). Studying student attrition. New Directions for Institutional Research, No. 36. San Francisco: Jossey-Bass.

Patton, M. Q. (2002). Qualitative Research and Evaluation Methods (3rd ed.). Thousand Oaks, CA: Sage Publications, Inc.

Smedley, B. D., Myers, H. F., \& Harrell, S. P. (1993). Minority-status stresses and the college adjustment of ethnic minority freshmen. Journal of Higher Education, 64(4), 435-452.

Solorzano, D., Ceja, M., \& Yosso, T. (2000). Critical race theory, racial microaggressions, and campus racial climate: The experiences of African American college students. The Journal of Negro Education, 69, 60-73.

Strauss, A. C., \& Corbin, J. (1990). Basics of qualitative research: Grounded theory procedures and techniques. London: Sage.

Tinto, V. (1975). Dropout from higher education: A theoretical synthesis of recent research. Review of Educational Research, 45, 89-125.

Tinto, V. (1987). Leaving college: Rethinking the causes and cures of student attrition. Chicago: The University of Chicago Press. 